Ophthalmologica

\title{
The 12th CIBA Vision Symposium
}

November 25, 1999, Osaka

November 27, 1999, Tokyo

Proceedings

Guest Editors

Yoshihisa Oguchi, Tokyo

Yoshihito Honda, Kyoto 
The current publication was made possible by an educational grant from

\section{CIBA Vision K.K.}

Professional Services Group

Tennoz Central Tower 13F

2-2-24 Higashi-Shinagawa, Shinagawa-ku

Tokyo 140-0002 (J apan)

S. Karger

Medical and Scientific Publishers Basel $\cdot$ Freiburg $\cdot$ Paris $\cdot$ London New York $\cdot$ New Delhi $\cdot$ Bangkok Singapore $\cdot$ Tokyo $\cdot$ Sydney
Drug Dosage

The authors and the publisher have exerted every effort to ensure that drug selection and dosage set forth in this text are in accord with current recommendations and practice at the time of publication. However, in view of ongoing research, changes in government regulations, and the constant flow of information relating to drug therapy and drug reactions, the reader is urged to check the package insert for each drug for any change in indications and dosage and for added warnings and precautions. This is particularly important when the recommended agent is a new and/or infrequently employed drug.
All rights reserved.

No part of this publication may be translated into other languages, reproduced or utilized in any form or by any means, electronic or mechanical, including photocopying, recording, microcopying, or by any information storage and retrieval system, without permission in writing from the publisher or, in the case of photocopying, direct payment of a specified fee to the Copyright Clearance Center (see 'General Information')

(c) Copyright 2001 by S. Karger AG,

P.O. Box, CH-4009 Basel (Switzerland)

Printed in Switzerland on acid-free paper by

Reinhardt Druck Basel

ISBN 3-8055-7204-2

\section{KARGER}

Fax+4161306 1234

E-Mailkarger@karger.ch

www.karger.com 
Ophthalmologica

\section{Contents}

The 12th CIBA Vision Symposium

1 Lectures in the Past

4 Organizing Committee

7 Opening Address

Lectures

9 Presentation of the Speaker

10 Retinal Translocation: Rationale and Results Eugene de Juan, Jr. (Baltimore, Md.)

20 Presentation of the Speaker

22 Mucosal Immune System: Close Encounter in the Uncharted World of Immunology

Hiroshi Kiyono (Osaka)

33 Presentation of the Speaker

35 Advancements in Extended-Wear Contact Lenses

Melvin I. Freeman (Seattle, Wash.)

Panel Discussions

47 Panel Discussion - Tokyo

51 Panel Discussion - Osaka

\section{KARGER}

Fax+4 41613061234

E-Mail karger@karger.ch

www.karger.com
(C) 2001 S. Karger AG, Basel

Access to full text and tables of contents, including tentative ones for forthcoming issues: www.karger.com/journals/oph/oph_bk.htm 